Research Article

\title{
Study on impact of maternal CD4 count on birth outcomes and mother to child transmission of HIV infection
}

\author{
Anita Nyamagoudar*, Mruthyunjaya S, Murugesh Patil, C. R. Banapurmath
}

Department of Pediatrics, JJM Medical College, Davangere, Karnataka, India

Received: 04 June 2016

Revised: 14 June 2016

Accepted: 06 July 2016

\section{*Correspondence:}

Dr. Anita Nyamagoudar,

E-mail: anitanyamagoud@yahoo.co.in

Copyright: (C) the author(s), publisher and licensee Medip Academy. This is an open-access article distributed under the terms of the Creative Commons Attribution Non-Commercial License, which permits unrestricted non-commercial use, distribution, and reproduction in any medium, provided the original work is properly cited.

\begin{abstract}
Background: To study the effect of antenatal maternal CD4 count on prematurity, low birth weight and vertical transmission among HIV positive pregnant women in settings with increased uptake of exclusive breastfeeding as infant feeding option.

Methods: Design of the study was prospective study. 3 hospitals attached to EGPAF PPTCT Centre at Bapuji Child Health Institute, JJM Medical College, Davangere. 50 Mother-baby pairs attending PPTCT centre. Main outcome measures: prematurity, low birth weight, infant feeding option and vertical transmission of HIV in relation to maternal CD4 count.

Results: Prematurity rates were 13.6\% (3/22) and (3/28) mothers with CD4 cell count below and above 350 cells/mm3 respectively. Low birth weight rates were $36.3 \%(8 / 22)$ and $35.7 \%(10 / 28)$ mothers with CD4 cell count below and above 350 cells/mm3 respectively. Vertical transmission of HIV was $3.6 \%(1 / 28)$ and $4.5 \%(1 / 22)$ among mothers with CD4 count above and below 350cells $/ \mathrm{mm} 3$ respectively. There was no statistically significant association between low maternal CD4 count and adverse birth outcomes and also vertical transmission of HIV. Mothers opting for exclusive breastfeeding were $100 \%(22 / 22)$ and $82.1 \%(23 / 28)$ with CD4 cell count below and above 350 cells $/ \mathrm{mm} 3$ respectively (p 0.04). At the same time, rates of vertical transmission did not vary between the two groups of mothers ( $\mathrm{p} 0.86$ ).

Conclusions: Low maternal CD4 count did not affect birth outcomes and vertical transmission of HIV. Mother-tochild transmission of HIV remained below $<5 \%$ while significantly increasing number of mothers took up breastfeeding as infant feeding option.
\end{abstract}

Keywords: Breastfeeding, HIV, Low birth weight, Perinatal transmission, Prematurity

\section{INTRODUCTION}

The prevention of mother-to-child transmission (PMTCT) is a highly effective intervention and has huge potential to improve both maternal and child health. From 2001 to 2012, there was a 52\% decline in new HIV infections among children. Expanded access to services to prevent mother to-child transmission prevented more than 670000 children from acquiring HIV from 2009 to
2012. ${ }^{1}$ For the first time, the elimination of parent-tochild transmission of HIV is now considered a realistic public health goal and an important part of the campaign to achieve the millennium development goals. In the last few years, new evidence on ARV prophylaxis to prevent HIV transmission from parent-to-child and optimal timing of ART initiation has been accumulated. Once implemented, these interventions could reduce Parent to Child Transmission of HIV to less than $5 \%$ in 
breastfeeding population from a background risk of $35 \%$ and to less than $2 \%$ in non-breastfeeding populations from a background risk of $25 \% .^{2}$

The frequent revision of maternal CD4 cut-off by WHO, to initiate HAART in pregnant mothers necessitates studies for determining impact of low CD4 counts on birth outcomes and vertical transmission of HIV in settings with increased uptake of exclusive breastfeeding as infant feeding option.

\section{METHODS}

All the mothers who were admitted for delivery underwent voluntary counselling and testing for HIV after taking consent from the mothers. HIV positive mothers underwent post-test counselling and CD4 count estimation was done. Based on the CD4 counts and haemoglobin concentration, mothers were categorised to receive ARV/ART according to WHO guidelines. HIV infected mothers who took regular antenatal care with CD4 count estimation were included in the study. Mothers who did not undergo CD4 count estimation and who did not give consent for the study were excluded from the study.

At the onset of labour mother received appropriate drug regimen based on duration of ARV prophylaxis. For the purpose of the study, HIV reactive mothers were categorized according to CD4 count into 2 groups. One group consisted of mothers with CD4 count above 350 cells/mm and the other with CD4 count below 350 cells $/ \mathrm{mm}^{3}$ After the delivery, baby was resuscitated with universal precautions and Nevirapine suspension was administered based on weight of the baby. Birth weight less than $2.5 \mathrm{~kg}$ was defined as low birth weight. Gestational age was assessed using modified Ballard scoring and antenatal USG when available. Gestational age below 27 weeks was defined as prematurity.

Exclusive breastfeeding was recommended for the first 6 months. Replacement feeding was considered only if all the 6 criteria for replacement feeding were met. Stopping of breastfeeding was advised gradually over one month, abrupt stoppage was discouraged. Meanwhile Nevirapine administration was continued till one week after the cessation of breastfeeding. Infants on replacement feeding were advised commercial infant formula milk. Infants in this group received NVP for $1^{\text {st }} 6$ weeks of life.

Regular follow up of babies was done for a period of 18 months with special emphasis on nutritional status, immunisation, opportunistic infections and psychosocial aspects.

All the infants underwent $1^{\text {st }}$ HIV DNA PCR at 6 weeks, 2 months (in case of replacement feeding) and in infants on breastfeeding, $2^{\text {nd }}$ DNA PCR at 6 months (in case of replacement feeding) and in infants on breastfeeding, $2^{\text {nd }}$ DNA PCR was at done 6 weeks after cessation of breastfeeding. Rapid test for antibodies was done at 18 months. Infants with positive DNA PCR were sent another whole blood sample for confirmation.

Maternal factors such as nutrition, socio-economic status, education were also analysed among the two groups of mothers. All the babies received Cotrimoxazole prophylaxis starting at 6 weeks of age till the 2nd DNA PCR result was negative. Complete professional confidentiality was maintained throughout the study period. Data was analysed by Chi square test and $\mathrm{p}$ value was obtained.

WHO, in 2012 has recommended triple antiretroviral drug regimen to all pregnant HIV positive women irrespective of CD4 count and to be continued for life. (Option $\mathrm{B}+$ ).58This recommendation makes CD4 count estimation obsolete. But, PPTCT centres in India are presently rolling out option B and heavily rely on CD4 count for management of HIV infected mothers. Thus, this study contributes to the observation that with effective antiretroviral coverage, maternal CD4 count does not affect the transmission rates.

\section{RESULTS}

$44 \%(22 / 50)$ of the mothers enrolled in the study had CD4 count $<350$ cells $/ \mathrm{mm}^{3}$. Rest $56 \%(28 / 50)$ of the mothers had CD4 count above 350 cells $/ \mathrm{mm}^{3}$. Low birth weight rates were $36.3 \%(8 / 22)$ among mothers with CD4 cell count below 350 cells $/ \mathrm{mm}^{3}$ and $35.7 \% \quad(10 / 28)$ mothers with CD4 cell count above 350 cells $/ \mathrm{mm}^{3}$ However, there was no statistically significant association between low maternal CD4 count and low birth weight. $(\mathrm{p}=0.96)$.

Prematurity rates were $13.6 \%$ (3/22) among mothers with CD4 cell count below 350 cells/mm and $10.7 \%(3 / 28)$ mothers with CD4 cell count above 350 cells $/ \mathrm{mm}^{3}{ }^{3}$ There was no statistically significant difference in prematurity rates with respect to maternal CD4 counts $(p=0.75)$.

$82.1 \%(23 / 28)$ of mothers with CD4 cell count above 350 cells $/ \mathrm{mm}^{3}$ and all the 22 mothers with CD4 count $<350$ cells $/ \mathrm{mm}^{3}$ took up exclusive breastfeeding. Statistically significant increase in number of mothers took up exclusive breastfeeding among mothers with CD4 counts below 350 cells $/ \mathrm{mm}^{3}$ ( $\left.\mathrm{p}=0.04\right)$.

The rate of vertical transmission of HIV was $3.6 \%(1 / 28)$ among mothers with CD4 count above 350 cells $/ \mathrm{mm}$ and $4.5 \%(1 / 22)$ among mothers with CD4 count below 350cells $/ \mathrm{mm}^{3}$ There was no statistically significant association between low maternal CD4 count and mother-to-child transmission of HIV ( $\mathrm{p}=0.86)$. The overall transmission rate was $4 \%$.

Maternal anaemia $(\mathrm{Hb}<10 \mathrm{~g} / \mathrm{dl})$ was found in $56 \%$ of mothers with CD4 count $<350$ cells $/ \mathrm{mm}$ and in $50 \%$ of mothers with CD4 cell count $>350$ cells $/ \mathrm{mm}^{3}$ However, 
the difference was not statistically significant among both groups of mothers $(\mathrm{p}=0.34)$. Maternal education, socio economic status, maternal weight at enrolment into
PPTCT centre and mode of delivery did not have significant difference among the two groups of mothers.

Table 1: Maternal and infant characteristics.

\begin{tabular}{|c|c|c|c|c|c|c|}
\hline Demography & Category & Total & Cd4 count $<350(n=22)$ & $\begin{array}{l}\text { Cd4 count }>350 \\
(n=28)\end{array}$ & $\chi^{2}$ & P value \\
\hline \multirow[t]{2}{*}{ Mother hb } & $<10 \mathrm{~g} / \mathrm{dl}$ & $28(56 \%)$ & $14(63.6 \%)$ & $14(50 \%)$ & 0.93 & $0.34, \mathrm{~ns}$ \\
\hline & $>10 \mathrm{~g} / \mathrm{dl}$ & $22(44 \%)$ & $8(36.3 \%)$ & $14(50 \%)$ & & \\
\hline \multirow[t]{3}{*}{$\begin{array}{l}\text { Maternal } \\
\text { education }\end{array}$} & No schooling & $8(16 \%)$ & $4(18.2 \%)$ & $4(14.3 \%)$ & 0.71 & $0.70, \mathrm{~ns}$ \\
\hline & $1^{\mathrm{st}}-10^{\mathrm{th}} \mathrm{std}$ & $38(76 \%)$ & $17(77.3 \%)$ & $21(75 \%)$ & & \\
\hline & $\begin{array}{l}\text { College and } \\
\text { above }\end{array}$ & $4(8 \%)$ & $1(4.5 \%)$ & $3(10.7 \%)$ & & \\
\hline \multirow{2}{*}{$\begin{array}{l}\text { Monthly } \\
\text { income }\end{array}$} & $<5000$ & $38(76 \%)$ & $15(68.2 \%)$ & $23(82.1 \%)$ & 1.32 & $0.25, \mathrm{~ns}$ \\
\hline & $>5000$ & $12(24 \%)$ & $7(31.8 \%)$ & $517.9 \%)$ & & \\
\hline \multirow{4}{*}{$\begin{array}{l}\text { Maternal } \\
\text { weight }\end{array}$} & $30-40 \mathrm{~kg}$ & $7(14 \%)$ & $4(18.2 \%)$ & $3(10.7 \%)$ & & \\
\hline & $41-50 \mathrm{~kg}$ & $21(42 \%)$ & $11(50 \%)$ & $10(35.7 \%)$ & 3.52 & $0.32, \mathrm{~ns}$ \\
\hline & $51-60 \mathrm{~kg}$ & $16(32 \%)$ & $4(18.2 \%)$ & $12(42.9 \%)$ & & \\
\hline & $>60 \mathrm{~kg}$ & $6(12 \%)$ & $3(13.6 \%)$ & $3(10.7 \%)$ & & \\
\hline \multirow[t]{2}{*}{ Drug regime } & Arv & $29(58 \%)$ & $3(13.6 \%)$ & $26(92.9 \%)$ & 31.74 & $0.00, \mathrm{hs}$ \\
\hline & Haart & $21(42 \%)$ & $19(86.4 \%)$ & $2(7.1 \%)$ & & \\
\hline \multirow{2}{*}{$\begin{array}{l}\text { Mode of } \\
\text { delivery }\end{array}$} & Lscs & $18(36 \%)$ & $7(31.8 \%)$ & $11(39.3 \%)$ & 0.30 & $0.59, \mathrm{~ns}$ \\
\hline & Ftnd & $32(64 \%)$ & $15(68.2 \%)$ & $17(60.7 \%)$ & & \\
\hline \multirow[t]{2}{*}{ Sex of baby } & Male & $27(54 \%)$ & $11(50 \%)$ & $16(57.1 \%)$ & 0.25 & $0.62, \mathrm{~ns}$ \\
\hline & Female & $23(46 \%)$ & $11(50 \%)$ & $12(42.9 \%)$ & & \\
\hline \multirow[t]{2}{*}{$\begin{array}{l}\text { Gestational } \\
\text { age }\end{array}$} & Term & $44(88 \%)$ & $19(86.4 \%)$ & $25(89.3 \%)$ & 0.10 & $0.75, \mathrm{~ns}$ \\
\hline & Preterm & $6(12 \%)$ & $3(13.6 \%)$ & $3(10.7 \%)$ & & \\
\hline \multirow[t]{2}{*}{ Birth weight } & Normal bw & $32(64 \%)$ & $14(63.6 \%)$ & $18(64.3 \%)$ & 0.002 & $0.96, \mathrm{~ns}$ \\
\hline & Lbw & $18(36 \%)$ & $8(36.3 \%)$ & $10(35.7 \%)$ & & \\
\hline \multirow[t]{2}{*}{$\begin{array}{l}\text { Feeding } \\
\text { option }\end{array}$} & Ebf & $45(90 \%)$ & $22(100 \%)$ & $23(82.1 \%)$ & 4.37 & $0.04, \mathrm{~s}$ \\
\hline & $\mathrm{Rf}$ & $5(10 \%)$ & 0 & $5(17.9 \%)$ & & \\
\hline \multirow{2}{*}{$\begin{array}{l}\text { Infant HIV } \\
\text { status }\end{array}$} & Positive & $2(4 \%)$ & $1(4.5 \%)$ & $1(3.6 \%)$ & 0.03 & $0.86, \mathrm{~ns}$ \\
\hline & Negative & $48(96 \%)$ & $21(95.5 \%)$ & $27(96.4 \%)$ & & \\
\hline
\end{tabular}

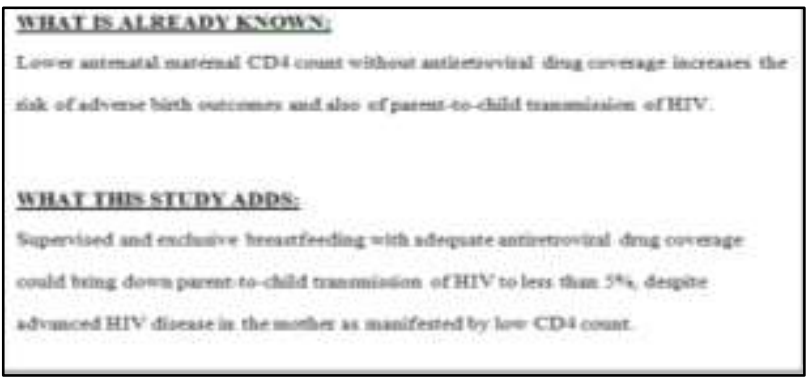

Figure 1: Figure shows what is already known and what this study adds.

\section{DISCUSSION}

WHO is recommending that HIV-positive mothers or their infants take antiretroviral drugs throughout the period of breastfeeding and until the infant is 12 months old. This means that the child can benefit from breastfeeding with very little risk of becoming infected with $\mathrm{HIV}^{3}$

A South African study by Van Den Merwe et al showed significant association between low maternal CD4 count and low birth weight. ${ }^{4}$ The low birth weight rates in the present study were $36 \%$. As per UNICEF/WHO estimates 
of the incidence of low birth weight, India has LBW rates of $30 \%$ in general population. ${ }^{5}$ Our study showed higher rates of low birth weight compared to UNICEF estimates. However, low maternal CD4 count was not associated with low birth weight in the present study.

Ezechiet al studied incidence of and socio-biologic risk factors for spontaneous preterm birth in HIV positive Nigerian women. ${ }^{6}$ There was significant association between CD4 count $<200$ and prematurity and with increasing CD4 counts, rates of prematurity reduced. ( $p=$ $0.008, S)$

Prematurity rates in the present study are $12 \%$. Our study showed no significant association between low maternal CD4 count and prematurity. The rates of prematurity were comparable to WHO estimates of prematurity for India in $2010(10-<15 \%)^{7}$

A multicentre based study by Kumwenda showed that decline in maternal CD4 count (per decrease of 100 units) significantly increased rates of vertical transmission. ${ }^{8}$ (p $.01, \mathrm{~S})$. In the present study, $4 \%(2 / 50)$ of the infants were infected with HIV. Low maternal CD4 count $(<350$ cells $/ \mathrm{mm}^{3}$ ) had no significant impact on mother-to-child transmission of HIV infection.

The most important observation of the study was that all the mothers with CD4 count $<350$ cells/mm opted for exclusive breastfeeding with mother-to-child transmission rates of $4.5 \%(1 / 22) .^{3}$ The transmission rates in the present study are in agreement with the latest WHO observation that, transmission rates can be reduced to less than $5 \%$ in breastfeeding population from a background risk of $35 \%$ provided adequate antiretroviral drug coverage is given to mother-baby pairs with supervised breastfeeding. These results indicate that in resource limited settings, extended NVP prophylaxis till breastfeeding period is an effective intervention to reduce MTCT of HIV. In the replacement fed group $0 \%$ transmission has been achieved in our study.

However, other maternal characteristics such as anaemia, weight at enrolment into antenatal clinic, education, socioeconomic status and mode of delivery were comparable between the two groups of mothers.

In the present study, $42 \%$ of the mothers received HAART therapy, either based on CD 4 count $<350$ cells/ mm or WHO clinical staging 3 or $4 .^{3}$ With this, there was significant reduction in rates of vertical transmission (4\%). Thus, HAART definitely contributes to reduction in vertical transmission and will always remain a recommended practice.

The Kesho Bora study shows that providing a combination of three ARVs to pregnant and breastfeeding mothers is a safe and effective way to reduce HIV transmission to infants particularly those born to women with a CD4 count below 200 and 350 cells $/ \mathrm{mm}^{3}$. ${ }^{9}$ Studies have shown that, maximal effectiveness of prevention of mother-to-child transmission (PMTCT) programs is achieved by initiating HAART at least 13 weeks prior to delivery. ${ }^{10}$ A study conducted at Botswana by Shapiro et al showed that all regimens of HAART from pregnancy through 6 months postpartum in breastfeeding mothers resulted in high rates of virologic suppression, with an overall rate of mother-to-child transmission of $1.1 \% .^{11}$

WHO, in 2012 has recommended triple antiretroviral drug regimen to all pregnant HIV positive women irrespective of CD4 count and to be continued for life. (Option $\mathrm{B}+)^{12}$ This recommendation makes CD4 count estimation obsolete. But, PPTCT centres in India are presently rolling out option $\mathrm{B}$ and heavily rely on CD4 count for management of HIV infected mothers. Thus, this study contributes to the observation that with effective antiretroviral coverage, maternal CD4 count does not affect the transmission rates with increased uptake of exclusive breastfeeding as infant feeding option.

\section{ACKNOWLEDGEMENTS}

Authors would like to thank EGPAF (Elizabeth Glaser Pediatric Aids Foundation) for their constant support, SAATHII (Solidarity and Action against The HIV Infection in India) for guidance, Medical Director Bapuji $\mathrm{CHI}$ for kind information to take up this study and thank all the counselors and Field Staff of EGPAF Centre for PPTCT at Bapuji CHI for all the help.

Funding: No funding sources

Conflict of interest: None declared

Ethical approval: The study was approved by the Institutional Ethics Committee

\section{REFERENCES}

1. Global report: UNAIDS report on the global AIDS epidemic 2013.

2. Antiretroviral drugs for treating pregnant women and preventing HIV infection in infants: recommendations for a public health approach. 2010 version. WHO.

3. Bulletin of the World Health Organization. Breast is always best, even for HIV-positive mothers. Available http://www.who.int/bulletin/volumes/88/1/10030110/en/.

4. Merwe KVD, Hoffman R, Black V, Chersich M, Coovadia A, Rees H. Birth outcomes in South African women receiving highly active antiretroviral therapy: a retrospective observational study. J Int AIDS Soc. 2011;14:42.

5. United Nations Children's Fund and World Health Organization, Low Birthweight: Country, regional and global estimates. UNICEF. New York; 2004.

6. Oliver C EzechiEmail author, Agatha N David, Chidinma V Gab-Okafor, Harry Ohwodo, David A 
Oladele, Olufunto O Kalejaiye. Incidence of and socio-biologic risk factors for spontaneous preterm birth in HIV positive Nigerian women. BMC Pregnancy and Childbirth 2012, 12:93. Available at:http://www.biomedcentral.com/1471-2393/12/93.

7. Born too soon: The Global Action Report on Preterm Birth. World Health Organization 2012.

8. Kumwenda NI, Hoover DR, Mofenson LM, Thigpen MC, Kafulafula G, Qing Li. Extended Antiretroviral Prophylaxis to Reduce Breast-Milk HIV-1 Transmission. N Engl J Med. 2008;359:11929.

9. World Health Organization 2011. Policy Brief. Department of reproductive health and research kesho bora study. Preventing mother-to-child transmission of HIV during breastfeeding.

10. Chibwesha CJ, Giganti MJ, Putta N, Chintu N, Jessica Mulindwa, Dorton BJ. Optimal Time on
HAART for Prevention of Mother-to-Child Transmission of HIV. J Acquir Immune Defic Syndr. 2011;58(2):224-8.

11. Shapiro RL, Hughes, Ogwu A, Kitch D, Lockman S, Moffat C. Antiretroviral regimens in Pregnancyand Breast-Feeding in Botswana. N Engl J Med. 2010;362:2282-94.

12. WHO programmatic update: use of antiretroviral drugs for treating pregnant women and preventing HIV infection in infants: executive summary. 2012.

Cite this article as: Nyamagoudar A, Mruthyunjaya S, Patil M, Banapurmath CR. Study on impact of maternal CD4 count on birth outcomes and mother to child transmission of HIV infection. Int J Community Med Public Health 2016;3:2083-7. 